\title{
Opieka specjalistyczna w obliczu kryzysu suicydalnego dzieci
}

\section{Professional care in the presence of suicide among children}

\begin{abstract}
ABSTRAKT: Samobójstwa stanowią drugą po wypadkach samochodowych przyczynę zgonów wśród dzieci i młodzieży w Polsce. Prawo krajowe i system opieki zdrowia nie są do tego przygotowane. W artykule na podstawie badań własnych z lat 2019-2021 autorka ukazała na przykładzie m.st. Warszawy główne problemy opieki specjalistycznej (ze strony szkoły, poradni psychologiczno-pedagogicznych, szpitali i oddziałów psychiatrycznych dla dzieci) w sytuacji kryzysu suicydalnego dzieci. Trudności te stanowią dobry wstęp do dyskusji publicznej i zmian w zakresie pomocy interwencyjnej, także w Polsce. W artykule przedstawiono wnioski z badań i rekomendacje działań wspierających system, które stworzone zostały na podstawie opinii specjalistów pracujących z dziećmi i z młodzieżą w Warszawie oraz rodziców dzieci w kryzysie psychicznym (szczególnie doświadczających depresji, mających myśli samobójcze i będących po próbach samobójczych).
\end{abstract}

SŁOWA KLUCZOWE: samobójstwo dzieci, kryzys suicydalny, psychiatria dziecięca, opieka pedagogiczna, opieka psychologiczna, zapobieganie samobójstwom

ABSTRACT: Suicide is the second leading cause of death among children and adolescents in Poland, after car accidents. The national law and the health care system are not prepared for it. In the article, based on my own research from 2019-2021, I try to show the main problems of specialized care in the situation of suicidal crisis of children in Warsaw. However, the difficulties are a good introduction to public discussion and changes in the field of intervention assistance. In this article I present conclusions from the research and recommendations for actions to support the system. It was created on the basis of the opinions of specialists working with children and adolescents in Warsaw and parents of children in psychical crisis.

KEYWORDS: suicide among children, suicidal crisis, child psychiatry, pedagogical care, psychological care, suicide prevention 


\section{Wstęp}

Kryzys jest subiektywnym odczuwaniem lub doświadczeniem wydarzenia albo sytuacji jako: niemożliwej do rozwiązania (towarzyszy temu ból i cierpienie), wyczerpującej zasoby jednostki (poczucie utraty, bezradności), przekraczającej dotychczasowe sposoby radzenia sobie $\mathrm{z}$ trudnościami ${ }^{1}$. W wielu przypadkach przerodzić się może w kryzys suicydalny - uczucia skłaniające do myśli samobójczych i podejmowanie prób odebrania sobie życia, także przez najmłodszych.

Według danych Światowej Organizacji Zdrowia (WHO) co piąty nastolatek ma problemy psychiczne lub behawioralne ${ }^{2}$. Polskie statystyki potwierdzają ten trend, który uwidacznia się również w kontekście decyzji ostatecznych. W 2020 r. policja odnotowała wśród dzieci i młodzieży 106 samobójstw oraz niemal ośmiokrotnie więcej prób samobójczych. Najczęstszymi powodami tego kroku okazały się: choroby psychiczne, kłopoty miłosne, brak wsparcia oraz konflikty i przemoc w rodzinie ${ }^{3}$. Na podjęcie decyzji o zakończeniu życia wpływa najczęściej wypadkowa suicydogennych układów sytuacyjnych, na które składa się przynajmniej kilka okoliczności ${ }^{4}$. Jednym z głównych zagrożeń jest depresja, w tym młodzieńcza, która jest jeszcze nie do końca znana, a czynniki ryzyka stale się poszerzają ${ }^{5}$.

Przyczyny wielu problemów zdrowia psychicznego dzieci i młodzieży w Polsce wiążą się z niską jakością, wąskim zakresem oraz utrudnioną dostępnością do opieki profilaktyczno-leczniczej i pomocy socjalnej, co z kolei jest przejawem braku spójnej i konsekwentnej polityki państwa wobec zapewnienia bezpieczeństwa i ochrony zdrowia dzieci ${ }^{6}$.

Profilaktyka oraz powszechna ochrona zdrowia psychicznego dzieci stanowią jedne $\mathrm{z}$ najistotniejszych aspektów zapewnienia najmłodszym bezpieczeństwa i zadbania o ich kondycję psychiczną. Szybkie wykrycie problemów i od-

1 K. Kraska, S. Żyża, Interwencja wobec dzieci i młodzieży $w$ obliczu sytuacji kryzysowych. Dzieci i młodzież w kryzysie, materiały Ośrodka Interwencji Kryzysowej, https://docplayer.pl/10789039-Osrodek-interwencji-kryzysowej-ul-dalibora-1-01-439-warszawa.html [dostęp: 31.05.2020].

2 Skuteczna pomoc w kryzysach psychicznych. W całej Polsce powstaja pilotażowe ośrodki wsparcia, https://www.gov.pl/web/zdrowie/skuteczna-pomoc-w-kryzysach-psychicznych-w-calejpolsce-powstaja-pilotazowe-osrodki-wsparcia [dostęp: 20.11.2019].

3 Zamachy samobójcze od 2017 roku, http://statystyka.policja.pl/st/wybrane-statystyki/zamachy-samobojcze/63803,Zamachy-samobojcze-od-2017-roku.html [dostęp: 25.05.2020].

4 B. Hołyst, Model motywacji zachowań samobójczych, w: Suicydologia, red. B. Hołyst, t. 4, LexisNexis Polska, Warszawa 2008, s. 85-87.

5 J. Szymańska, Zapobieganie samobójstwom dzieci i młodzieży. Poradnik dla pracowników szkół i placówek oświatowych oraz rodziców, Ośrodek Rozwoju Edukacji, Warszawa 2016, s. 14.

6 E. Respond, Prawne aspekty ochrony zdrowia dzieci w Polsce, „Roczniki Nauk Prawnych” 2014 , t. 24 , nr 3, s. $42-56$. 
powiednie reagowanie mogą niwelować długotrwałe konsekwencje. Skuteczne działania zapobiegawcze i pomoc interwencyjna w zakresie zachowań suicydalnych są możliwe dzięki oparciu się na wiedzy i interdyscyplinarnych badaniach naukowych.

Celem artykułu jest przyjrzenie się sytuacji opieki specjalistycznej dla dzieci i młodzieży w sytuacji kryzysu suicydalnego. Na podstawie badań własnych staram się ukazać główne problemy pojawiające się w opiece psychologicznej i psychiatrycznej w Warszawie. Przyglądając się opinii specjalistów pracujących z dziećmi i z młodzieżą oraz zbierając wypowiedzi rodziców dzieci doświadczających depresji lub myśli samobójczych, stworzyłam rekomendacje mające znaczenie $\mathrm{w}$ tworzeniu opieki nad zdrowiem psychicznym najmłodszych. W artykule staram się wskazać główne problemy w funkcjonowaniu systemów pomocy psychiatrycznej i psychologicznej dla dzieci i ich rodzin.

\section{Metodologia badań}

Artykuł powstał na podstawie moich badań na temat funkcjonowania w Warszawie w 2019 r. opieki psychologicznej i psychiatrycznej dla dzieci doświadczających kryzysu psychicznego (szczególnie depresja i zachowania samobójcze) oraz na podstawie badań własnych w ramach przygotowywania na Uniwersytecie Warszawskim rozprawy doktorskiej na temat samobójstw dzieci (lata 2019-2021). W ramach badań wymienionych jako pierwsze przeprowadziłam 329 ankiet z pytaniami otwartymi i zamkniętymi, 16 wywiadów ze specjalistami ze szkół i z poradni psychologiczno-pedagogicznych oraz $21 \mathrm{wy}$ wiadów z rodzicami dzieci mających depresję lub kryzys suicydalny. Analizie poddałam także fora internetowe, na których znaleźć można zapytania o pomoc psychologiczną i psychiatryczną dla dzieci w Warszawie. Przygotowując rozprawę doktorską, zebrałam 497 kwestionariuszy wypełnionych przez specjalistów pracujących z dziećmi. W Warszawie zapytania ankietowe wysłałam do 722 placówek pomocowych i oświatowych w każdej z 18 dzielnic. Kwestionariusze w obydwu badaniach składały się z pytań zamkniętych i otwartych, które dotyczyły zagadnien takich jak: występowanie problemów psychicznych u uczniów wszystkich poziomów szkół warszawskich, współpraca między instytucjami (szkoła, poradnie, NGO, psychiatrzy), dostępność psychiatrów i psychologów w Warszawie, trudności spotykane na co dzień w świadczeniu usług pomocowych i wspierających, znajomość procedur interwencyjnych $\mathrm{w}$ przypadku myśli i zachowań samobójczych dzieci, znajomość ośrodków pomocowych dla dzieci wymagających opieki psychologicznej i psychiatrycznej, rozpoznawanie depresji, zachowań samobójczych u dzieci, pomysły na działania profilaktyczne i ochronne $\mathrm{w}$ zakresie zapobiegania samobójstwom najmłodszych. W ramach prowadzonych badań skupiłam się na opiece psychiatrycznej jako wtórnej 
względem wsparcia interwencyjnego oraz na podstawowej pomocy pedagogicznej i psychologicznej. Uwagę zwróciłam na wiedzę specjalistów codziennie pracujących z dziećmi, szczególnie pracowników warszawskich szkół i poradni psychologiczno-pedagogicznych. Wnioski stanowią rekomendację do działań profilaktycznych dla instytucji rządowych i pozarządowych, świadczących pomoc w zakresie ochrony zdrowia psychicznego dzieci i młodzieży, szczególnie w zakresie przeciwdziałania samobójstwom i depresji dzieci.

\section{Sytuacja psychiatrii dziecięcej w Polsce}

Liczbę psychiatrów na oddziale prowadzącym świadczenia psychiatryczne dla dzieci i młodzieży obejmujące ich diagnostykę i leczenie reguluje Rozporządzenie w sprawie świadczeń gwarantowanych z zakresu opieki psychiatrycznej i leczenia uzależnień z 19 czerwca 2019 r. W załączniku pierwszym tego dokumentu znajdziemy informację, że na 16 lóżek szpitalnych powinien przypadać: lekarz specjalista $\mathrm{w}$ dziedzinie psychiatrii lub lekarz specjalista $\mathrm{w}$ dziedzinie psychiatrii dzieci i młodzieży albo psychiatrii dziecięcej, lub lekarz, który posiada specjalizację I stopnia w dziedzinie psychiatrii albo psychiatrii dzieci i młodzieży, lub lekarz w trakcie specjalizacji w dziedzinie psychiatrii albo psychiatrii dzieci i młodzieży, pracując na jeden pełny etat. Liczba pracowników wpływa na szybkość i jakość interwencjī. Według danych Najwyższej Izby Kontroli w Polsce w 2019 r. brakowało ok. 300 lekarzy tej specjalności. Zawód psychiatry dzieci i młodzieży wykonywało 419 lekarzy, a 169 odbywało specjalizację. Dodatkowo niekorzystna była również struktura wiekowa kadry lekarskiej, albowiem 32\% specjalistów miało powyżej 55 lat. Sytuacja nie ulega poprawie. Nieliczne miejsca specjalizacyjne $\mathrm{w}$ zakresie psychiatrii zostały obsadzone rezydentami (39 miejsc ze 161 dostępnych). Obecnie lekarze niechętnie wybierają tę specjalizację ${ }^{8}$.

Dodatkowym problemem w skali ogólnokrajowej jest nierównomierne rozmieszczenie w kraju pomocy specjalistycznej (względem województw oraz wybranych miast, jak np. Warszawa i Kraków - które dominują w swoich województwach - wobec np. Radomia lub Tarnowa) oraz lekarzy: „Najmniej lekarzy tej specjalności, przypadających na 10 tys. osób małoletnich było w województwie lubuskim $(0,16)$, a najwięcej - w województwie łódzkim $(0,79)$. Natomiast psychiatrów przypadających na 1 tys. pacjentów małoletnich, najmniej było

7 Załącznik nr 1 w: Rozporządzenie Ministra Zdrowia z dnia 19 czerwca 2019 r. w sprawie świadczeń gwarantowanych z zakresu opieki psychiatrycznej i leczenia uzależnień (Dz.U. z 2019 r., poz. 1285).

${ }^{8}$ NIK o dostępności lecznictwa psychiatrycznego dla dzieci i młodzieży, https://www.nik.gov. pl/aktualnosci/lecznictwo-psychiatryczne-dzieci-i-mlodziezy.html [dostęp: 5.05.2021]. 
w województwie podkarpackim $(1,02)$ a najwięcej - również w województwie łódzkim $(4,96)$ "'9.

W odpowiedzi na rozwijający się kryzys psychiatrii dziecięcej w 2019 r. powstał raport stworzony przez Sieć Obywatelską Watchdog ${ }^{10}$. Ukazuje on obecną sytuację tej gałęzi służby zdrowia w Polsce. Województwo mazowieckie pod względem miejsc i możliwości opieki ma liczebną przewagę nad innymi regionami w Polsce ${ }^{11}$, co miało znaczenie przy opracowywaniu wyników moich badań. Raport wskazuje na problemy systemowe i organizacyjne państwa polskiego w zakresie ochrony zdrowia psychicznego dzieci. Brakuje łóżek w szpitalach psychiatrycznych, szczególnie w okresie jesiennym. Przyjmowane są przede wszystkim dzieci, u których stwierdza się zagrożenie życia lub zdrowia, a i dla nich nie zawsze jest miejsce inne niż na korytarzu. Praca na oddziale jest stresująca i cechuje się dużą odpowiedzialnością. Brakuje miejsc pomocowych, gdzie dzieci otrzymałyby wparcie psychologiczne i gdzie zagwarantowano by szybką interwencję kryzysową ${ }^{12}$. Wnioski z tego badania stały się dla mnie inspiracją do pogłębienia wiedzy na temat sytuacji pomocowej dla dzieci w kryzysie suicydalnym w stolicy. Zebrane przeze mnie informacje pokrywają się $\mathrm{z}$ danymi $\mathrm{z}$ wymienionego raportu.

\section{Warszawski głos o kryzysowej pomocy specjalistów}

Warszawski system ochrony zdrowia psychicznego dzieci ma szeroką ofertę pomocową. Począwszy od zatrudnienia w szkołach psychologów i pedagogów szkolnych, przez poradnie psychologiczno-pedagogiczne w każdej dzielnicy, aż po szeroką ofertę organizacji pozarządowych finansowanych w ramach projektów miejskich. Przeprowadzone przeze mnie badania sprawdzają, jak oferta ta wygląda w praktyce. Rozpatruję również możliwości związane z ograniczeniem potrzeby hospitalizacji dzieci na rzecz działań systemowych, które podejmowane będą już w szkołach. Być może nie chodzi o to, aby powiększać szpitale i szukać psychiatrów dziecięcych, których w tym momencie brakuje na rynku pracy. Być może warto pomyśleć, co zrobić, aby wielu problemom zapobiec,

9 Ibidem.

10 R. Maślankiewicz, M. Bójko, Raport Watchdoga. Jak źle jest w polskiej psychiatrii dzieci $i$ młodzieży, https://siecobywatelska.pl/raport-watchdoga-jak-zle-jest-w-polskiej-psychiatriidzieci-i-mlodziezy/ [dostęp: 30.04.2020].

11 Informacja ta miała znaczenie $\mathrm{w}$ doborze próby w moich badaniach dotyczących pomocy specjalistycznej dla dzieci i młodzieży. Wybrałam Warszawę jako miasto wielu możliwości pomocowych w przypadku kryzysu suicydalnego dzieci. Za zasadną uznałam informację, że wszelkie braki w pomocy warszawskiej mają wpływ na pomoc psychiatryczną i psychologiczną w całym kraju.

12 R. Maślankiewicz, M. Bójko, Raport Watchdoga..., s. 9. 
eliminując czynniki, które powodują kryzysy suicydalne. W celu poszerzenia wiedzy w tym temacie warto przyjrzeć się wypowiedziom osób bezpośrednio w system pomocy zaangażowanych.

Główny wniosek w opinii specjalistów pracujących z dziećmi w Warszawie, którzy brali udział w moim badaniu, dotyczy braku dostępu do bezpłatnej pomocy lekarzy psychiatrów, psychoterapeutów i do szybkiej interwencji psychologicznej. Konsultacje prywatne są drogie (ok. $250 \mathrm{zł}$ za wizytę) i również często niedostępne od zaraz. Pierwsze spotkanie to czasami dopiero początek długiej drogi leczenia, wiążącej się z oczekiwaniem na realizację skierowań. Na problem ten uwagę zwrócili ankietowani psycholodzy i pedagodzy szkolni:

„Wielokrotnie proponowałam rodzicom chęć i potrzebę współpracy - bez odzewu. Nie dziwi mnie to, psychiatrów jest mało, a potrzeby ogromne" - pedagog warszawskiego liceum.

„Nie ma współpracy, brak specjalistów” - psycholog szkoły podstawowej.

„Znam kilka miejsc, do których kieruję rodziców. W placówkach NFZ terminy są tak odlegle, że dziecko nie ma szans na pomoc w chwili, kiedy tego najbardziej oczekuje. W niektórych szpitalach dzieci »uczą się» od siebie. Ilość personelu jest zdecydowanie niewystarczająca. Raczej nakłonię rodziców do wizyt prywatnych" - pedagog szkoły podstawowej ${ }^{13}$.

W badaniach prowadzonych dla m.st. Warszawy przeprowadziłam wywiady z rodzicami dzieci, które doświadczają depresji, załamania psychicznego, mają myśli samobójcze lub są po próbach samobójczych. Zebrane informacje pokazują praktyczną stronę pomocy psychiatrycznej i psychologicznej w Warszawie, której na co dzień doświadczają rodzice szukający wsparcia i ratunku dla swoich podopiecznych ${ }^{14}$ :

„Szukałam pomocy w Internecie, trudno jest znaleźć dobre opinie. Znalazłam jednak fundację, która doradziła mi, co mam robić" - mama dziewczynki chorej na anoreksję.

„Jest zdecydowanie za mało informacji, gdzie szukać pomocy. Jedni odsyłają do drugich, ze względu na długie kolejki. Rzadko ktoś umie wskazać, gdzie tej kolejki nie będzie" - mama chłopca, który chciał popełnić samobójstwo.

13 Wypowiedzi pochodzą z badania prowadzonego przeze mnie dla m.st. Warszawy w $2019 \mathrm{r}$. Kwestionariusze z pytaniami otwartymi i zamkniętymi wypełniło 321 specjalistów pracujących w warszawskich szkołach i ośrodkach pomocowych. Badania były anonimowe.

14 Zebrałam 21 wywiadów z rodzicami, którzy w ostatnim czasie (2019 r.) korzystali z pomocy psychologów, psychiatrów dziecięcych i psychoterapeutów lub ogólnej pomocy w ramach działań poradni psychologiczno-pedagogicznych w Warszawie. 
„Bardzo wstydziłam się iść z dzieckiem do psychiatry. Chciałam, aby szkoła o tym nie wiedziała" - mama dziewczynki z depresją ${ }^{15}$.

W badaniach zebrałam także wypowiedzi internautów. Opinie dobierałam celowo. Szukałam rodziców, którzy poszukiwali wsparcia oraz pomocy psychologicznej i psychiatrycznej dla swoich dzieci w Internecie:

Re: Psychiatra dziecięcy 09.11.18, 08:54: Trudno z psychiatrami dziecięcymi. Jest ich mało a kolejki ciągną się niemiłosiernie - prywatnie. Państwowo np. w przychodni przyszpitalnej na Żwirki i Wigury nawet 6 miesięcy. Diagnoza i opieka możliwa jest w [...] miejscach prywatnych ${ }^{16}$.

21.03.2018 13:23: Monalizz Fakt dziś ciężko o dobrego psychologa jak i o dobrego lekarza ;) Obeznani w temacie wiedzą jak jest ;) Ta nasza państwowa służba zdrowia też nie daje spokojnie spać w nocy. Nie o takiej rzeczywistości się kiedyś myślało chyba :/17.

lauren6Re: Psychiatra dziecięcy 09.11.18, 13:30: Raczej przyszykuj się na wielomiesięczną (o ile nie kilkuletnią) kolejkę na NFZ lub na diagnozę w prywatnym gabinecie za kilkaset $\mathrm{z}^{18}$.

Przyglądając się cytowanym wypowiedziom, należy stwierdzić, że potrzebne jest wzmocnienie systemu opieki specjalistycznej dla dzieci doświadczających kryzysów psychicznych, także suicydalnych, i szukających pomocy w stolicy.

\section{Opieka specjalistyczna wobec kryzysu suicydalnego}

W ramach prowadzonych przeze mnie badań dowiedziałam się, jaka jest opinia na temat pomocy specjalistycznej według internautów, specjalistów pracujących $\mathrm{z}$ dziećmi i z rodzicami oraz rodzin poszukujących pomocy psychologów i psychiatrów. Wyniki zebrałam i uporządkowałam tematycznie. Warto na nie zwrócić uwagę, rozpatrując stan pomocy kryzysowej w Warszawie i nie tylko.

W Internecie pojawiają się zapytania rodziców, opiekunów i specjalistów dotyczące opieki pedagogicznej, psychologicznej i psychiatrycznej dzieci. Według internautów na rynku brakuje specjalistów w tych dziedzinach, szczególnie

15 Wywiady przeprowadzone zostały anonimowo. Ankietowani byli dobierani celowo, na podstawie doświadczenia w korzystaniu z pomocy psychologicznej i psychiatrycznej dla dzieci w Warszawie.

16 https://forum.gazeta.pl/forum/w,567,167111928,167111928,Psychiatra_dzieciecy.html [dostęp: 2.12.2019].

17 https://tustolica.pl/forum_dobry-psycholog.warszawa/topic/6-14726 [dostęp: 15.11.2019].

18 https://forum.gazeta.pl/forum/w,567,167111928,167111928,Psychiatra_dzieciecy.html [dostęp: 2.12.2019]. 
w ramach działań Narodowego Funduszu Zdrowia (dane na przykładzie m.st. Warszawy). W licznych wpisach widać bezradność rodziców wobec problemów, które pojawiły się w ich życiu. Użytkownicy forum Gazeta.pl opisują, w jaki sposób znaleźć dla dziecka rzetelną, szybką, sprawdzoną i jak najlepszą pomoc. Zainteresowanie tematyką psychiatrów i psychologów dziecięcych w Warszawie wzrasta $\mathrm{w}$ okresie jesienno-zimowym. Informacje na forach internetowych są często przedstawiane chaotycznie. Wątki są wymieszane tematycznie. Pojawiają się tam też liczne reklamy placówek prywatnych. Są one podkreślane w osobnych wątkach, ale także włączane $\mathrm{w}$ rozmowy użytkowników. W czasie pandemii COVID-19 wzrosła popularność porad online. Konsultacje psychologiczne i psychiatryczne prowadzone w ten sposób mają niższą stawkę godzinową niż spotkanie osobiste. Cena wizyty u psychiatry dziecięcego wynosi ok. $250 \mathrm{zł}$, u psychologa 150-200 zł. Wizyta online kosztuje ok. 100 zł. Telefony zaufania dla dzieci i młodzieży są bardzo łatwe do wyszukania w przestrzeni internetowej.

We wnioskach wyróżnić należy pochwały dotyczące współpracy szkół (psycholodzy/pedagodzy) z poradniami psychologiczno-pedagogicznymi. Według specjalistów $\mathrm{z}$ różnych instytucji funkcjonuje ona prawidłowo. $\mathrm{W}$ warszawskich szkołach i placówkach pomocowych najczęściej pojawiające się wśród dzieci objawy to: lęk, zaburzenia zachowania, częste zmiany nastroju, depresja, myśli samobójcze. Nauczyciele, psycholodzy i pedagodzy wskazywali coraz częściej występujące samookaleczenia i szerzej rozumianą autoagresję. Do najczęściej spotykanych przez specjalistów trudnych zachowań możemy zaliczyć: agresję słowną, nadpobudliwość, uzależnienia behawioralne, napady złości. Przyczyny wszelkich kryzysów psychicznych dzieci są złożone i wieloaspektowe. Specjaliści podkreślają brak umiejętności wychowawczych rodziców i opiekunów, w tym brak konsekwencji i nieumiejętność stawiania granic, przezwyciężenie czego może wesprzeć szersza oferta pomocowa i edukacyjna skierowana do nich.

Najistotniejszym elementem systemu pomocy psychiatrycznej jest szkoła. To ta instytucja ma pierwszy kontakt $\mathrm{z}$ uczniem, a zespół psychologiczno-pedagogiczny stanowi fundament wszelkich działań interwencyjnych w placówkach. Nauczyciele wskazują psychologa i pedagoga szkolnego jako podstawę działań interwencyjnych i pomocowych. To oni mają znać procedury i wiedzieć wszystko. Problemem jest jednak niewystarczająca liczba psychologów i pedagogów w szkołach oraz w przedszkolach. Zbyt mała liczba specjalistów w placówkach pierwszego kontaktu powoduje natłok spraw i niedokładność działań, stąd tylko $70 \%$ odpowiadających stwierdziło, że pomoc specjalistyczna w szkołach jest wystarczająca, aby pomagać w kryzysie. Według pracowników szkół współpraca z psychiatrami w Warszawie nie istnieje. Stan psychiatrii jest na poziomie przeciętnym. Brakuje psychiatrów dziecięcych, a można wręcz powiedzieć, że ich nie ma. Konieczne jest kierowanie do placówek prywatnych, które też nie zawsze są dostępne. Z powodu słabej współpracy instytucji i niewystarczającej liczby 
specjalistów dziecko doświadczające kryzysu nie zawsze otrzymuje pomoc. Zbyt często także dzieci przekierowuje się do innych osób zajmujących się wsparciem. Brakuje psychoterapeutów dziecięcych.

Potrzebne działania pomocowe skupiają się przede wszystkim na profilaktyce uniwersalnej, czyli kierowaniu do wszystkich przekazów mówiących o walce ze stereotypami na temat chorób psychicznych oraz o walce ze stereotypami dotyczącymi pomocy psychiatrycznej i psychologicznej. Niezbędne jest podnoszenie świadomości społeczeństwa w tych tematach. Potrzebne są również działania w zakresie profilaktyki selektywnej, skierowanej do wybranych grup już zagrożonych ryzykiem kryzysu psychicznego. Szczególne działania powinny być poświęcone umiejętnościom wychowawczym rodziców.

Bardzo ważnym elementem spójnej ochrony zdrowia psychicznego dzieci w Warszawie jest współpraca między instytucjami - której według specjalistów jest za mało. Potrzebnych jest więcej placówek pracujących z podopiecznymi środowiskowo. Istotne jest, aby wszelkie działania pomocowe kierowane były systemowo - do dzieci i do ich rodziców.

Trzeba także zauważyć, że brakuje kampanii informacyjnych na temat problemów psychicznych dzieci, w tym kryzysów suicydalnych. Istnieje niska społeczna świadomość w kwestii tego, co dzieciom może dolegać i jak ważna jest rozmowa oraz dostrzeganie ich emocji. Rodzice chwalą pracę psychologów i pedagogów w szkołach oraz działania poradni psychologiczno-pedagogicznych. Wyrażają natomiast swoją niemoc, jeśli chodzi o poszukiwanie terapii długoterminowych po otrzymanych diagnozach. Brakuje również zajęć socjoterapeutycznych, treningów umiejętności społecznych, treningów zastępowania agresji.

\section{Rekomendacje}

W świetle danych zgromadzonych podczas moich badań, szczególnie opierając się na wieloaspektowych opiniach specjalistów, uważam za istotne podjęcie debaty publicznej zainteresowanych środowisk, na podstawie której wprowadzone zostaną kompleksowe działania, skuteczne w ochronie zdrowia psychicznego dzieci i młodzieży w Polsce. Opisuję tu ogólne kierunki działań, które wymagają skonkretyzowania rozwiązań dla działań lokalnych. Najważniejsze z nich to:

- wdrożenie i przeprowadzenie ciągłych działań w zakresie profilaktyki zdrowia psychicznego dzieci i młodzieży (zarówno profilaktyka uniwersalna, jak i selektywna) - powinny one zostać skierowane do dzieci, rodziców i specjalistów oraz być realizowane na każdym etapie rozwoju dzieci. Należy kształtować umiejętności społeczne, uczyć rozpoznawania emocji, komunikacji. W działaniach profilaktycznych istotne są także kampanie społeczne przełamujące stereotypy, uwrażliwiające i uczące pomocy dzieciom będącym w potrzebie; 
- wzmocnienie działalności przedszkoli i szkół - należy wzmocnić pozycję pedagogów i psychologów szkolnych, zadbać o ich doszkolenie w zakresie zdrowia psychicznego dzieci i nauczyć adekwatnie reagować, na samym początku kryzysu. Warto tworzyć kampanie społeczne dla pracowników oświaty dotyczące zdrowia psychicznego dzieci; zachęcać kadrę pedagogiczną do tworzenia kampanii lokalnych; ograniczyć czas poświęcany na sporządzenie dokumentacji (dzienniki, sprawozdania) na rzecz intensyfikacji pracy z dziećmi i ich rodzicami;

- wzmocnienie i przeformułowanie zadań poradni psychologiczno-pedagogicznych - należy wzmocnić działania środowiskowe. Istotne jest nowe zdefiniowanie poradni psychologiczno-pedagogicznych (PPP) w systemie oświaty, które pomoże w zmniejszeniu liczby pacjentów czekających długo na porady psychiatryczne. Działania PPP są chwalone przez rodziców i specjalistów. W związku z tym warto je rozbudować, uściślając współpracę między szkołami a poradniami, co może stanowić pierwszy krok wychodzenia z kryzysu. Zamiast odsyłać dalej, to oni wspólnie mogą podejmować działania ratunkowe i zapobiegawcze. Warto wzmocnić współpracę poradni zdrowia psychicznego z poradniami psychologiczno-pedagogicznymi oraz ze szkołami; uprościć kontakt z tymi placówkami (czasami bardzo trudno się tam dodzwonić, nie zawsze jest możliwość zapisu przez Internet); prowadzić miejskie projekty o charakterze ochrony zdrowia psychicznego - działania edukacyjne, ale także interwencyjne. Należy stworzyć jasny przekaz - również w Internecie gdzie szukać pomocy, gdzie kierować dzieci tej pomocy potrzebujące; działać w myśl zasady: „lepiej zapobiegać, niż leczyć”;

- podejmowanie działań w zakresie prawnej ochrony dobra dzieci - warto wprowadzić w ramach struktur pomocy społecznej możliwość działań wyspecjalizowanej kadry działającej interwencyjnie na zasadzie psychologicznej pomocy środowiskowej. Należy dążyć do poprawy współpracy interdyscyplinarnej poprzez wspólne działania szkół, poradni, pomocy społecznej, kuratorów; wprowadzić do szkół jednolite procedury interwencyjne i wymagać ich przestrzegania; stale podnosić kompetencje specjalistów różnych instytucji i organizacji, nie tylko związanych ze zdrowiem dzieci. Trzeba umożliwić dzieciom kończącym 18 lat zakończenie psychoterapii na oddziałach psychiatrycznych dla młodzieży; wprowadzić ujednolicone przepisy dotyczące tylko dzieci - przepisy „porozrzucane” po różnych aktach prawnych, pisane często w niezrozumiały sposób, utrudniają bowiem pracę specjalistom;

- wzmocnienie współpracy między instytucjami, szczególnie w zakresie przepływu informacji;

- ustalając kierunki polityki wsparcia dla rodzin oraz usług edukacyjnych i zdrowotnych dla dzieci, należy tworzyć rozwiązania dążące do wyrównywania szans rodzin i dzieci będących w trudnej sytuacji. Trzeba zapewnić równy dostęp do różnorodnych form opieki i edukacji dla dzieci, dbając o wy- 
soką jakość tych działań; uwrażliwiać rodziców na wagę czasu, który powinni poświęcać swoim dzieciom - umożliwić im to poprzez, w miarę możliwości, elastyczny czas pracy.

Przedstawione rekomendacje to tylko część możliwości wskazanych dla poprawy opieki psychiatrycznej i psychologicznej dzieci. Stanowić one mogą jednak podstawę dyskusji i podstawę do usprawnienia działań pomocowych.

\section{Wnioski rodziców i nauczycieli w Warszawie na temat profilaktyki}

Profilaktyka i działania zapobiegające samobójstwom powinny koncentrować się przede wszystkim na nauce komunikacji i budowania relacji. Potrzebne są kampanie rozwijające wiedzę ogólną na temat wszelkich problemów psychicznych, warsztaty profilaktyczne dla dzieci, rodziców i nauczycieli. Z tej przyczyny, pisząc o opiece specjalistycznej w sytuacji kryzysu suicydalnego, warto pokazać, jakie rekomendacje dają rodzice i nauczyciele będący w bezpośrednim kontakcie $\mathrm{z}$ dzieckiem.

Zbierając różne odpowiedzi i reakcje rodziców, stworzyłam listę krótkich porad dla rodziców od rodziców oraz od rodziców dla nauczycieli. Uwagi przedstawiam łącznie ze względu na bardzo podobne komunikaty. Lista porad rodziców dla rodziców i nauczycieli zawiera następujące hasła: chcieć dostrzec, pokonać strach $\mathrm{w}$ reagowaniu, działać jak najszybciej, rozmawiać ze swoimi dziećmi i traktować je poważnie, nie pouczać, nie oceniać, dawać szansę, być cierpliwym, kochać, słuchać, widzieć, prosić o pomoc, szukać jej i nie dawać za wygraną, być silnym, chcieć widzieć i chcieć działać ${ }^{19}$.

\section{Podsumowanie}

Zebrane informacje na temat problemów występujących w opiece psychologicznej i psychiatrycznej dla dzieci w Warszawie oraz stworzone rekomendacje są tylko częścią możliwości wskazanych dla poprawy opieki psychiatrycznej i psychologicznej dzieci. Na podstawie moich badań starałam się ukazać spis możliwości zgłaszanych przez specjalistów i rodziców. Wnioski ukazują także codzienne trudności $\mathrm{w}$ realizacji założeń ochrony zdrowia psychicznego dzieci i młodzieży, z różnych perspektyw. Wprowadzenie przemyślanych, kompleksowych i jednolitych działań usprawniających ochronę zdrowia najmłodszych

19 Porady rodziców i nauczycieli pochodzą z badania prowadzonego przeze mnie dla m.st. Warszawy w 2019 r. Powstały na podstawie wywiadów przeprowadzonych z rodzicami i nauczycielami. 
przyniesie pozytywne rezultaty nie tylko dla działu medycznego, ale też dla edukacji i innych działań na rzecz rodzin. Jest to sieć, której elementy są ze sobą ściśle połączone i od siebie zależne. Zdrowie rodziny, podstawowej komórki społecznej, jest fundamentem sprawnie działającego systemu w ogóle.

Podsumowując, usprawnienie działań na rzecz opieki psychologicznej i psychiatrycznej wymaga czasu i jak najszerszych konsultacji społecznych, włączając w nie: dzieci, rodziców, specjalistów z zakresu działań rządowych, samorządowych i pozarządowych, podmioty prywatne oraz organizacje religijne. Tylko współpraca i stałe działania profilaktyczne mogą polepszyć stan obecnej opieki psychiatrycznej i psychologicznej w Warszawie oraz w całej Polsce i wzmocnić pomoc dla dzieci, także w kryzysie suicydalnym.

\section{Bibliografia}

Hołyst B., Model motywacji zachowań samobójczych, w: Suicydologia, red. B. Hołyst, t. 4, LexisNexis Polska, Warszawa 2008, s. 85-87.

http://forum.gazeta.pl/forum/w,567,167111928,167111928,Psychiatra_dzieciecy.html [dostęp: 2.12.2019].

https://tustolica.pl/forum_dobry-psycholog.warszawa/topic/6-14726 [dostęp: 15.11.2019].

Kraska K., Żyża S., Interwencja wobec dzieci i młodzieży w obliczu sytuacji kryzysowych. Dzieci i młodzież w kryzysie, materiały Ośrodka Interwencji Kryzysowej, https://docplayer.pl/10789039-Osrodek-interwencji-kryzysowej-ul-dalibora-1-01439-warszawa.html [dostęp: 31.05.2020].

Maślankiewicz R., Bójko M., Raport Watchdoga. Jak źle jest w polskiej psychiatrii dzieci $i$ młodzieży, https://siecobywatelska.pl/raport-watchdoga-jak-zle-jest-w-polskiejpsychiatrii-dzieci-i-mlodziezy/ [dostęp: 30.04.2020].

NIK o dostępności lecznictwa psychiatrycznego dla dzieci i młodzieży, https://www. nik.gov.pl/aktualnosci/lecznictwo-psychiatryczne-dzieci-i-mlodziezy.html [dostęp: 5.05.2021].

Respond E., Prawne aspekty ochrony zdrowia dzieci w Polsce, „Roczniki Nauk Prawnych" 2014, t. 24, nr 3, s. 42-56.

Skuteczna pomoc w kryzysach psychicznych. W całej Polsce powstaja pilotażowe ośrodki wsparcia, https://www.gov.pl/web/zdrowie/skuteczna-pomoc-w-kryzysach-psychicznych-w-calej-polsce-powstaja-pilotazowe-osrodki-wsparcia [dostęp: 20.11.2019].

Szymańska J., Zapobieganie samobójstwom dzieci i młodzieży. Poradnik dla pracowników szkót i placówek oświatowych oraz rodziców, Ośrodek Rozwoju Edukacji, Warszawa 2016.

Zamachy samobójcze od 2017 roku, http://statystyka.policja.pl/st/wybrane-statystyki/zamachy-samobojcze/63803,Zamachy-samobojcze-od-2017-roku.html [dostęp: 25.05.2020]. 


\section{mgr MARTA WRONA}

e-mail: martasabinasoczewka@gmail.com

Kryminolog, socjolog i pedagog. Doktorantka Katedry Kryminologii Uniwersytetu Warszawskiego. Specjalizuje się w suicydologii. Przygotowuje rozprawę doktorską na temat samobójstw dzieci. Zawodowo uczy, szkoli i wykłada.

Criminologist, sociologist, and educator. PhD student at the Department of Criminology at the University of Warsaw. She specializes in suicidology. She is preparing a doctoral dissertation on child suicides. In her professional life, she teaches, trains, and lectures. 